Karadeniz Uluslararası Bilimsel Dergi

Volume: 52, Winter-2021, p. (243-255)

ISSN: 1308-6200 DOI Number: https://doi.org/10.17498/kdeniz.1019340

Research Article

Received: Nov 5, 2021 | Accepted: Nov 27, 2021

This article has been checked for plagiarism.

\title{
ESTABLISHMENT OF MODERN DISASTER MANAGEMENT IN TURKEY: OPERATIONAL IMPROVEMENTS
}

\author{
TÜRKIYYE'DE MODERN AFET YÖNETIMININ KURULMASI: \\ OPERASYONEL İYİLESTTİRMELER
}

\section{СОВРЕМЕННОЕ УПРАВЛЕНИЕ БЕДСТВИЯМИ В ТУРЦИИ: ОПЕРАЦИОННЫЕ УЛУЧШЕНИЯ}

\section{Hikmet İSKENDER*}

\begin{abstract}
Natural disasters have been experienced more frequently in recent years for a variety of reasons including technological advances and climate change. These disasters cause a wide variety of problems, such as public health, environmental, and infrastructural problems. Turkey is a developing country and is geographically located in a region where natural disasters occur frequently and most of natural disasters are related to earthquakes. Disaster management systems are implemented to prevent the negative effects of natural disasters such as earthquakes. Marmara Earthquake in 1999 is the milestone of Disaster Management in Turkey and disaster management system changed and became effective after this earthquake. The aim of this study was to examine the earthquakes in Turkey from the past to the present in order to investigate the effects of the disaster management system in our country and make inferences about disaster management by using collected data. In the presented study, an overview of disaster management in Turkey was made, and by examining the functioning of disaster management systems operating in Turkey, the disaster management system for disasters that can be occur has been discussed. This paper evaluate the efficiency of disaster management system in Turkey. With the present paper, inferences about disaster management in Turkey were made with the determinations based on the earthquakes.
\end{abstract}

Keywords: disaster, management, natural disaster, earthquake, operations, EM-DAT

\section{ÖZ}

Doğal afetler, teknolojik gelişmeler ve iklim değişikliği dahil olmak üzere afetler çeşitli nedenlerle son yıllarda daha sık yaşanmaktadır. Bu afetler halk sağlığ sorunları gibi çeşitli sorunlara neden olmaktadır. Türkiye gelişmekte olan bir ülkedir ve

ORCID: 0000-0001-7442-3960, Asst. Prof. Dr. Disaster and Emergency Management Department, Disaster Management Institute, Istanbul Technical University, Maslak, Istanbul, Turkey, iskender@itu.edu.tr 


\section{Establishment of Modern Disaster Management in Turkey: Operational...}

coğrafi olarak doğal afetlerin sıklıkla meydana geldiği ve doğal afetlerin çoğunun depremlerle ilgili olduğu bir bölgede yer almaktadır. Deprem gibi doğal afetlerin olumsuz etkilerini önlemek için afet yönetim sistemleri uygulanmaktadır. 1999 Marmara Depremi Türkiye'de Afet Yönetiminin mihenk taşıdır ve bu depremden sonra afet yönetim sistemi değişmiş ve yürürlüğe girmiştir. Bu çalışmanın amacı, geçmişten günümüze Türkiye'deki depremleri incelemek, toplanan verilerden yararlanarak afet yönetimi hakkında çıkarımlarda bulunmak ve afet yönetim sisteminin ülkemizdeki etkilerini araştırmaktır. Sunulan çalışmada, Türkiye'de afet yönetimine genel bir bakış yapılmış ve Türkiye'de faaliyet gösteren afet yönetim sistemlerinin işleyişi incelenerek meydana gelebilecek afetler için afet yönetim sistemi tartışılmıştır. Bu makale, Türkiye'de afet yönetim sisteminin etkinliğini değerlendirmektedir. Bu çalışma ile depremlere dayalı tespitlerle Türkiye'de afet yönetimine ilişkin çıkarımlarda bulunulmuştur.

Anahtar Kelimeler: afet, yönetim, doğal afet, deprem, operasyonlar, EM-DAT

\section{АННОТАЦИЯ}

Бедствия, в том числе стихийные бедствия, технические неполадки и изменение климата, в последние годы по разным причинам случаются чаще. Эти бедствия вызывают различные проблемы, такие как проблемы со здоровьем, окружающей средой и инфраструктурой. Турция - развивающаяся страна, географически расположенная в регионе, где часто происходят стихийные бедствия, а большинство стихийных бедствий связано с землетрясениями. Системы управления стихийными бедствиями внедрены для предотвращения его негативных последствий, таких как землетрясения. Землетрясение 1999 года в Мраморном море является краеугольным камнем управления стихийными бедствиями в Турции и после этого землетрясения система управления стихийными бедствиями изменилась и вступила в силу. Целью этого исследования является изучение землетрясений в Турции от прошлого до настоящего для того, чтобы сделать выводы об управлении стихийными бедствиями с использованием собранных данных и изучить влияние системы управления стихийными бедствиями в нашей стране. В нижеследующем исследовании сделан обзор управления стихийными бедствиями в Турции, изучено функционирование действующих в Турции систем управления стихийными бедствиями, а также обсуждена система управления стихийными бедствиями на случай возможных стихийных бедствий. В этой статье оценивается эффективность системы управления стихийными бедствиями в Турции. В рамках этого исследования, выводы об управлении стихийными бедствиями в Турции были сделаны на основе определений, основанных на землетрясениях.

Ключевые слова: катастрофа, управление, стихийное бедствие, землетрясение, операции, EM-DAT.

\section{INTRODUCTION}

Disasters can be defined in a way that causes an unpleasant outcome. Research papers show that there are no permanent measures to prevent natural disasters. Disasters cause uneconomic damage to the environment and people in societies. Therefore, many researches and organizations have proposed various measures and strategies to reduce the vulnerability and impact of these events (Kumar et al. 2021, Cai et al. 2018). Vulnerability is one of the defining components of disaster risks or respond to a hazard once a disaster has occurred. It depends on several factors, such as age and health status of people, local environmental and 
sanitary conditions, quality and state of local buildings, and their location in relation to potential hazards. Actions taken to reduce vulnerabilities and risks to the environment and society are defined to be Disaster Management (DM) by International Federation from Red Cross. "DM is the organization and management of resources and responsibilities for dealing with all humanitarian aspects of emergencies, especially preparedness, response and recovery, to reduce the impact of disasters" (Parwanto \& Oyama 2014).

Natural disasters destroy physical assets such as buildings and equipment, thereby degrading productive capacity, and cause severe damage (Zhang et al. 2017; Denisenko \& Zeng 2020). However, natural disasters have mainly effected population and economic growth in disaster-prone areas. It can be safely stated that future losses from natural disasters are expected to increase due to continued increases in economic exposure.

Disasters cause significant damage to human capital, including death and destruction, have adverse effects on nutrition, education, health, and many incomegenerating processes. Moreover, some of these effects are both large and long lasting. In the case of disasters, the poor people of the society suffer the most and the effects remain in the society in the long run, which in some cases even leads to inadequacies and lack of plans to deal with such situations causing further disasters (Keating et al. 2017). Although the control of natural disasters seems to be out of the hands of authorities, there is an important area for policy action to minimize the impact on human capital accumulation. The policies and laws change the impact of disasters. The policy makers and their executors can revise the results of the disasters by examining the disasters that occurred in the past. This is a part of the disaster management cycle that takes place in the pre-disaster phases to change the impact of disasters by identifying and reducing vulnerabilities (Keating et al. 2017).

Disaster management efforts aim to reduce and prevent potential damage from hazards, provide prompt, appropriate assistance to victims of disasters, and achieve rapid and effective recovery. It is not possible to predict the risks and vulnerabilities caused by disasters in all circumstances. However, with the help of $\mathrm{DM}$, the vulnerabilities can be minimized. The damage and losses caused by disasters can be prevented and preparedness of disasters can improve. The policy makers have focused on developing approaches to encourage people in disaster preparedness programs. Disaster education aims to impart knowledge, improve skills, and motivate individuals and groups to reduce their vulnerability. Even educating vulnerable people can have a positive impact on others and the rest of the community. Disaster education is functional, operational, and cost-effective. Otherwise, low awareness and inadequate understanding of risk will negatively impact people's preparedness, response, and recovery. In this regard, gathering and disseminating knowledge and information about hazards, vulnerabilities and capacities, especially for vulnerable people, should be a priority. 


\section{OVERVIEW of DISASTERS in TURKEY}

Turkey is in a unique position geographically, with part of the country in Asia and the other part in Europe. Throughout history, the country has been three bridges to connect the two continents. Turkey is located at the intersection of the Balkans, Caucasus, Middle East and Eastern Mediterranean. Turkey often faces major natural disasters due to the negative nature of its land structure, soil form, and meteorological conditions. Natural disasters cause significant economic and life losses in Turkey. According to the database of Emergency Events Database (EMDAT), earthquakes, epidemics, extreme temperatures, floods, landslides, mass movements, storms, and wildlife are among the most common disasters in Turkey (Table 1).

Table 1. Natural disasters in Turkey from 1900 to 2021 (https://www.emdat.be/. Access date 01.08.2021).

\begin{tabular}{|l|c|}
\hline Type of Disasters & Frequency of Occurrence \\
\hline Earthquake & 110 \\
\hline Epidemic & 8 \\
\hline Extreme temperature & 7 \\
\hline Flood & 47 \\
\hline Landslide & 14 \\
\hline Mass movement (dry) & 1 \\
\hline Storm & 11 \\
\hline Wildfire & 5 \\
\hline
\end{tabular}


It can be seen that $54 \%$ of the natural disasters that occurred in Turkey from 1900 to 2021 are related to earthquakes. This means that Turkey is an earthquake-prone country. This data can be followed from Figure 1.

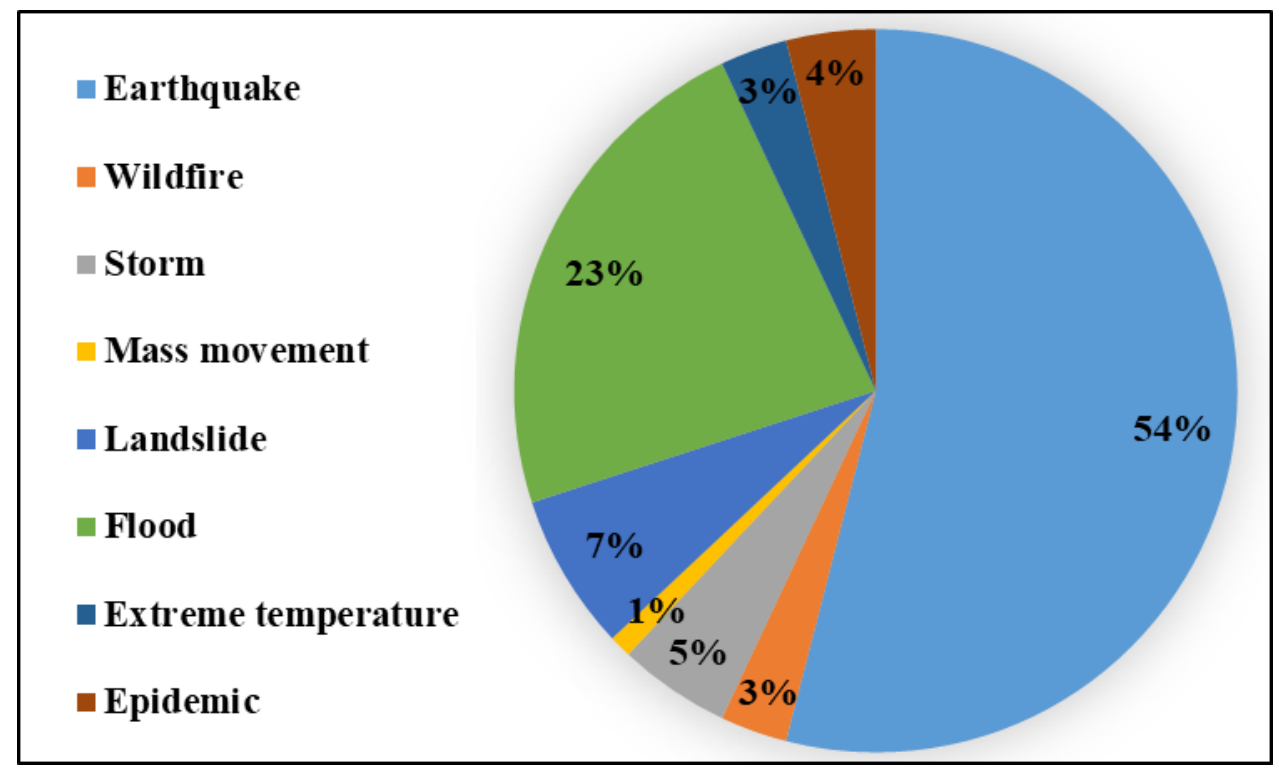

Figure 1. Frequency of occurrence of natural disasters in Turkey (https://www.emdat.be/. Access date 01.08.2021).

As it is known that Turkey is an active seismic zone in the complex collision zone of Eurasian plate and African and Arabian plates. Much of the country lies on Anatolian Plate, a small plate bounded by two major slip fault zones, the North Anatolia Fault and the Eastern Anatolia Fault. The western part of the country is also influenced by the tectonic pull zone of the Aegean Sea, which is formed by the southward displacement of Greek Arc. The eastern part of Turkey is located at the western end of the fold belt and the Zagros drift, which is dominated by the tectonic drift (Basabe 2015; Aydin 2016; Emre et al. 2018). Anatolian transform fault system is probably the most active in the world. The seismic hazard in Turkey is the highest along the plate boundaries but there is a significant risk of damaging earthquakes almost everywhere in the country.

From the Figure 2, it can be seen that the country ranks fourth in the world in terms of earthquakes. 


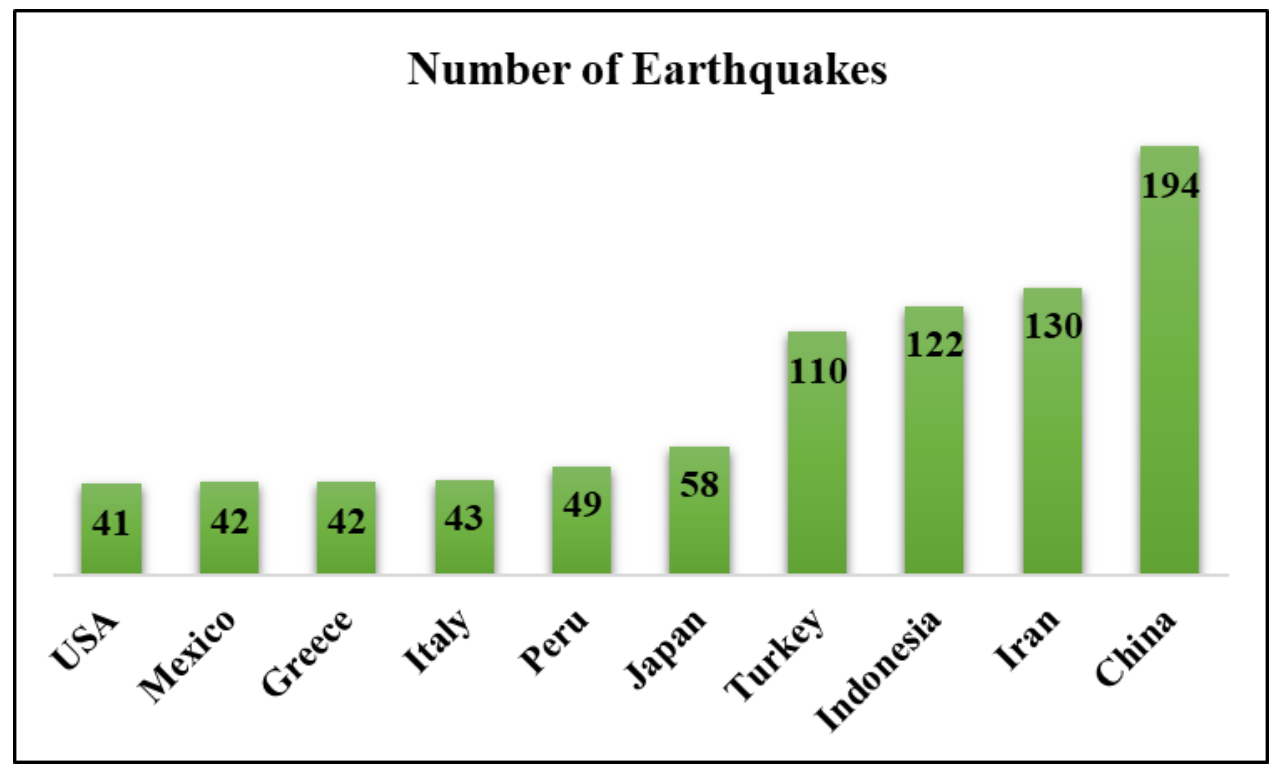

Figure 2. Global occurrences from ground movement disasters, 1900 to 2021 (https://www.emdat.be/. Access date 01.08.2021).

\section{DISASTER MANAGEMENT in TURKEY}

The aim of this study is to evaluate the efficiency of DM measures in Turkey based on the earthquakes from the past to the present. In general, DM is a long term process and it takes time for the outcome to be either positive or negative. The studies such as research in pre-disaster phases include studying previous and historical events, finding vulnerabilities and weaknesses, reducing and limiting risks, raising community awareness, defining, identifying key roles, establishing relationships for cooperation, achieving a comprehensive plan. These actions are a general part of the DM process. Each step and level of DM involves subsets of actions to achieve a desired outcome (Emre et al. 2018).

As it is known that Turkey is a country prone to natural disasters. The country has experienced severe natural disasters. Erzincan earthquake in 1992, Black Sea region flood in 1998, Adana-Ceyhan earthquake in 1998, Marmara Earthquake in 1999, Hakkari earthquake in 2004, and Sivas Landslide in 2005 are the six major natural disasters that have occurred in 30 years.

Among them, Marmara Earthquake in 1999 can be introduced as a starting point for creating an optimal DM system. This system have been adapted to international standards and updated with new studies and researches. Studies on DM in Turkey have changed from the past to the present.

Turkey needs a constantly evolving DM system that takes into account all aspects, since $95 \%$ of the country is located on one of the most active fault lines on earth. Severe earthquakes can occur in Turkey at any time, resulting in damage that requires a very complex management system. The reason that disasters can cause a 


\section{Hikmet İSKENDER}

lot of damage in Turkey is that $70 \%$ of Turkey's population lives in high hazard areas and, as mentioned earlier, $66 \%$ of the entire country is located on an active fault line. (Emre et al. 2018). In the recent years, it can be seen that researchers have focused on the study of phases before the disasters.

Unfortunately before 1999, the lack of an effective DM system amplified the impact of Marmara Earthquake on all of Turkey. That is why, this earthquake caused many people to migrate to other major cities, which in turn creates new problems. The earthquake also had an impact on the environment. In addition, the collecting the debris without prior knowledge caused some negative effects. The fires in the Gulf also killed fish, threatened agriculture, and caused air pollution and lung diseases. This natural disaster not only had a negative impact on the people in the region where the disaster occurred, but also had a direct impact on the taxpayers who had to pay for the costs. The wrong decisions made by builders and managers and the lack of proper insurance meant that the impact of this natural disaster was greater in Turkey. Also in 1999, the public deficit increased and the trade deficit worsened, as well as tax revenues decreased and foreign debt increased. It can be safely mentioned that the damage caused by the Marmara Earthquake revolutionized the whole Turkish DM system.

After the 1999 Marmara Earthquake, positive steps were taken to create a modern system DM. For example, a new emergency management agency was established (Ocal 2021; Dobrucali \& Demir 2016). New regulations for disaster preparedness, management, and response were also developed. In this new system, organizations and responsibilities were established. Responsibility for disaster damage assessment and reconstruction was given to Disaster Affairs Agency. The lack of insurance for natural disasters causes a lot of damage, which itself can be problematic. Therefore, measures were taken to create a suitable earthquake insurance in Turkey and Natural Disaster Insurance Agency (DASK) was established. This insurance company was able to create a support to reduce the country's financial vulnerability to earthquakes and transfer financial losses to the international insurance market. In addition, DASK have supported the mechanism of encouraging property owners to take out insurance and encouraging builders to build safer structures.

At the local level, the responsibility for response and rescue and the management of NGOs were brought under the control of the provincial capitals' crisis management. In this new system, municipalities were responsible for mitigation plans, public awareness, and educational projects. The use of NGOs and the public sector, voluntary personnel activities, coordination and cooperation also played an important role in this system (Ocal 2021).

With the establishment of AFAD in 2009, the DM system and legislature in Turkey evolved. AFAD was placed under the administration of the Turkish Prime Minister and all powers and responsibilities were brought under one roof. In 2018, AFAD was placed under the Interior Ministry by the order of the Turkish President. AFAD has a flexible and dynamic structure, and the agency cooperates with all other 


\section{Establishment of Modern Disaster Management in Turkey: Operational...}

national organizations and agencies with the aim of planning, managing, supporting, coordinating and implementing all major disaster prevention and response activities.

The main mission of the agency is to minimize loss outcomes and ensure post-disaster efforts. AFAD's first and most important operational mission was the 2011 Van earthquake, where AFAD's performance was evaluated and its strengths and weaknesses were discussed on various topics such as rescue operations, shelter services, administrative structure, psychosocial services, and infrastructure works. Based on the reports on AFAD's performance, the response time and services provided were within an acceptable range. Therefore, it can be concluded that the performance of AFAD in Van earthquake was effective and the establishment of this agency was the right decision. At this point, a new model of disaster management was implemented, which shifted the crisis management to the risk management. The integrated system have aim of identifying hazards and risks and minimizing the potential losses before the disaster occurs. After Van Earthquake, AFAD started working on a more effective disaster management policy covering all phases of the integrated DM and the preparation of the national plan became an effective initial step.

Turkey Disaster Response Plan (TDRP) covers all response actions required in the event of a disaster or emergency and defines in detail the processes, activities, roles, obligations, responsibilities, authorizations, cooperation involved at national and local levels. Compared to previous plans, TDRP has been treated with a comprehensive approach, the number of service groups has been increased, and the services have been thoroughly integrated. Staffing, equipment and resource analyses have been continued to be carried out regularly at central and local levels, supported by up-to-date SWOT analysis, to support the development and improvement of disaster scenarios, appropriate response methods and capacities in all respects. The aim of TDRP is to define the roles and responsibilities of ministry groups and coordination units involved in disaster and emergency response, and to establish the basic principles of the response plan in anticipation, during and after disasters. TDRP includes the personnel of ministries, public institutions, private and nongovernmental organizations. Another way that Turkey has in hand to develop the DM system in the country is the use of Public-Private Partnership (PPP). PPP became popular among governments to involve the private sector in the country's infrastructure and services. This way is used in developed countries in their disaster management system. Turkey is one of the top countries using PPP for development and improvement.

In Turkey, researches have been conducted and different ways and methods have been presented to integrate the DM with PPP. Turkish DM system can benefit from these methods in different ways (Auzzir et al. 2014).

\section{METHODOLOGY, RESULTS \& DISCUSSION}

The data used in this paper comes from the Emergency Events Database (EM-DAT) database from 1900 to early 2021. The EM-DAT is a database of natural and technological disasters available worldwide since 1988, containing core data on 


\section{Hikmet İSKENDER}

the impacts and consequences of nearly 22000 disasters. EM-DAT contains geographical, temporal, human and economic information on disasters at the country level. Therefore, it provides an objective basis for vulnerability assessment and rational decision making in disaster situations. It also provides information on the human impact of disasters, disaster-related economic loss estimates, and disasterspecific international assistance. The main objective of the database is to serve the purposes of humanitarian action at national and international levels.

EM-DAT is maintained by the Center for Research on the Epidemiology of Disasters at the School of Public Health of the Universite Catholique de Louvain in Brussels, Belgium (EM-DAT: 2021).

For a disaster to be included in the EM -DAT database, at least one of the following criteria should be met:

- $\quad$ Ten or more people are reported killed or one hundred or more are reported affected.

- A state of emergency is declared,

- A call for international assistance is made.

This study employed statistics to evaluate the trend of earthquakes, ground motions and human losses in Turkey from 1900 to early 2021 (Table 2). DM was analyzed by the result of these statistics. These trends helped the DM measures are effective or not.

Table 2. Sub-Periods (https://www.emdat.be/. Access date 01.08.2021).

\begin{tabular}{|l|c|}
\hline Sub-Periods & Number of Earthquakes \\
\hline I $(1900-1930)$ & 11 \\
\hline II $(1931-1960)$ & 34 \\
\hline III $(1961-1990)$ & 26 \\
\hline IV $(1990-2021)$ & 39 \\
\hline
\end{tabular}

First of all, the whole period from 1900 to the beginning of 2021 was divided into 4 sub-periods which correspond to almost 30 years. The data for each sub-period were examined separately. Comparisons between sub-periods according to the average earthquake frequency in each sub-period were made to determine the trend of earthquake increase in Turkey from 1900 to early 2021. Then, the comparison of the number of deaths in each sub-period was performed by taking the average number of deaths per day in each sub-period. The slope of the result in the graph showed the trend of deaths throughout the period. The data extracted from EM-DAT showed how many earthquakes with fatalities occurred each year.

Table 3 shows the frequency of earthquakes in each sub-period. The mean value given in the table for each sub-period was obtained by dividing the number of earthquakes by the number of years in that sub-period. 
Table 3. The frequency of earthquakes in Turkey (https://www.emdat.be/. Access date 01.08.2021).

\begin{tabular}{|c|c|c|c|}
\hline Sub-Periods & Total & Mean & Maximum \\
\hline I & 11 & 0.36 & 3 \\
\hline II & 34 & 1.13 & 2 \\
\hline III & 26 & 0.87 & 2 \\
\hline IV & 39 & 1.86 & 3 \\
\hline All & 110 & 0.9 & 3 \\
\hline
\end{tabular}

According to the mean values, the trend of earthquake occurrence in subperiod 1 to 2 had increased, from 2 to 3 there was a small decrease and from 3 to 4 there was again an increase. It can be said that the growth trend of the number of earthquake occurrence between sub-periods was variable with growth. However, when comparing the sub-period 1 and sub-period 3, there was a very large increase over the entire period. Moreover, the mean frequency of occurrence of earthquakes in the third period was higher than the mean of the whole period. Therefore, it can be concluded that in the last three decades, the frequency of earthquakes in Turkey has increased greatly.

Figure 4 shows the slope of the change line, which shows an increasing trend over the whole period according to the mean values obtained from the sub-periods. It can be seen that there was an urgent need to take measures to cope with disasters. This growing trend was linked to population growth and technological developments that exposed the communities and property to greater risk. The following section examined the trend in the number of fatalities over the entire period and sub-periods to see what impact the actions of DM have had on this process.

Table 4 shows the number of deaths from earthquakes in each sub-period. The mean values shown in this table were obtained by dividing the number of fatalities by the number of days in each sub-period. There was an increase from 1 to 2, a decrease from 2 to 3, and again an increase from 3 to 4 . There was an increase in the trend of deaths per day when comparing sub-periods 1 and 4 . The highest mean value belongs to sub-period 2, which means 4.7 deaths per day. If we compare subperiod 2 with sub-period 4, a significant decrease in the trend of deaths in the whole period was seen (Table 4). 
Table 4. Number of deaths per day in Turkey (https://www.emdat.be/. Access date 01.08.2021).

\begin{tabular}{|c|c|c|c|c|}
\hline Sub-Periods & Total & Sub-Period Days & Mean & Maximum \\
\hline I & 11686 & 11322 & 1.03 & 4000 \\
\hline II & 49875 & 10592 & 4.7 & 32962 \\
\hline III & 12459 & 10622 & 1.17 & 3840 \\
\hline IV & 19993 & 10958 & 1.8 & 17127 \\
\hline All & 94013 & 43494 & 2.1 & 32962 \\
\hline
\end{tabular}

The number of deaths per day decreased in the trend, which means that the measurements in the DM process in Turkey were positively effective throughout the period.

The present study examined earthquake trends in Turkey from 1900 to early 2021 to find out the trend of earthquakes in Turkey, as well as to examine the disaster management system throughout the period to determine its progress. The results show that this trend was ascending in Turkey from 1900 to present, where earthquakes occurred in high numbers. The results also showed a positive progress in disaster management in Turkey.

According to the results, it can be safely stated that Turkey is a country where natural disasters abound and measures have been taken to deal with them and save lives and not lose property. These measures should be proportional to Turkey's conditions because Turkey is geographically located in a place where there are active fault lines and an earthquake can occur at any moment. In Turkey, the disaster management system have constantly updated to create a safe environment and development with prevention. In all respects, Turkey have prepared to respond to natural disasters, taken special measures for each type of natural disaster and made necessary planning.

On the other hand, if we compare these results with a country like Iran, which is a developing country with similar cultural and geographical conditions, we can say that Turkey has a more optimal disaster management system. However, natural disasters are unpredictable and the risk can never be reduced to zero. Every country has its own shortcomings in disaster management in accordance with its internal conditions. This does not mean that the disaster management system in Turkey is weak. Studies show that this system in Turkey is well planned and the organizations and hierarchy of authorities related to disaster management are clearly known. In addition, the relevant authorities can contribute to the improvement by using the private sector in Turkey and increasing awareness and public knowledge. Allowing the private sector to enter this system actually helps to save time and costs. 


\section{CONCLUSION}

By examining disaster trends from the past to the present, we can identify where vulnerabilities and risks are hidden in the disaster management system, as well as the weaknesses and strengths of the systems during emergencies. The weaknesses can be managed and eliminated if possible, and the shortcomings of the system can be fixed and facilities and functions can be added. In this purpose, the earthquakes in Turkey from the past to the present were determined in order to examine the effects of the disaster management system of our country in this paper. The disaster management system in Turkey for natural disasters such as earthquakes was discussed. An overview of disaster management in Turkey was made by examining the functioning of disaster management systems operating in Turkey.

According the results of the paper, the disaster management system have updated to create a safe environment for life in Turkey. In all respects, Turkey have been preparing to respond to natural disasters such as earthquakes and making necessary planning.

\section{ACKNOWLEDGEMENT}

The author thanks Hamidreza Raouli Panah for kind help with data collection.

\section{REFERENCES}

AUZZIR, Z. A., HAIGH, R. P. \& AMARATUNGA, D. (2014). Public-private partnerships (PPP) in disaster management in developing countries: A conceptual framework. Procedia Economical Finance, 18, 807-814. doi: 10.1016/s2212-5671(14)01006-5.

AYDIN, M. (2016). Natural disasters in Turkey and natural disaster profile of Bursa. International Journal of Social Sciences, Humanities and Education, 3(4), 110. doi: 10.20431/2349-0381.0304001.

BASABE, P. (2015). Hyogo framework for action 2005-2015, (2013 ed.) Springer, Dordrecht. doi: https://doi.org/10.1007/978-1-4020-4399-4_180.

CAI, H., LAM, N. S. N., QIANG, Y., ZOU, L., CORRELL, R. M. \& MIHUNOV, V. (2018). A synthesis of disaster resilience measurement methods and indices. International Journal of Disaster Risk Reduction, 31(1), 844-855. doi: 10.1016/j.ijdrr.2018.07.015.

DENISENKO, A. \& ZENG, Z. (2020). The analysis of earthquake precursors in variations of TEC in the ionosphere and the subsequent impact on the environment. IOP Conference Series: Earth and Environmental Science, 421(2), 1-7. doi:10.1088/1755-1315/421/2/022034.

DOBRUCALI, E. \& DEMIR, I. H. (2016). Earthquake and Flood Disaster Management Regulations in Turkey. Disaster Science and Engineering, 2(1), 1-6.

EM-DAT Database. https://www.emdat.be/. Access date 01.08.2021

EMRE, O., DUMAN, T., OZALP, S., SAROGLU, F., OLGUN, S., ELMACI, H. \& CAN, T. (2018). Active fault database of Turkey. Bulletin Earthquake Engineering, 16(8), 3229-3275. doi: 10.1007/s10518-016-0041-2. 


\section{Hikmet İSKENDER}

KEATING, A., CAMPBELL, K., MECHLER, R., MAGNUSZEWSKI, P., MOCHIZIKU, J., LIU, W., SZOENYI, M. \& MCQUISTAN, C. (2017). Disaster resilience: What it is and how it can engender a meaningful change in development policy. Development Policy Review, 35(1), 65-91. doi: 10.1111/dpr.12201.

KUMAR, P. G., TEJASWINI, V., KESAVA RAO, P., \& SHANKAR, G. J. (2021). Disaster mitigation and its strategies in a global context- A state of the art. Material Today: Proceeding, 45(7), 6488-6492. doi: 10.1016/j.matpr.2020.11.369.

OCAL, A. (2021). Disaster management in Turkey: a spatial approach. International Journal of Disaster Risk Management, 1, 15-22.

PARWANTO, N. B. \& OYAMA, T. (2014). A statistical analysis and comparison of historical earthquake and tsunami disasters in Japan and Indonesia. International Journal of Disaster Risk Reduction, 7, 122-141. doi: 10.1016/j.ijdrr.2013.10.003.

ZHANG, W., XU, X. \& CHEN, X. (2017). Social vulnerability assessment of earthquake disaster based on the catastrophe progression method: a Sichuan Province case study. International Journal of Disaster Risk Reduction, 24, 361-372. doi: 10.1016/j.ijdrr.2017.06.022 